\title{
GEOMORPHOLOGICAL, PEDOLOGICAL STUDIES AND EVALUATION OF SOME SOILS IN WADI SUDR, SINAI PENINSULA, EGYPT
}

\author{
M.M. Soliman, I. A. Hegab and Salwa S. El- Sayied \\ Soils, Water \& Environment Research Institute, ARC, Giza, Egypt
}

Received: Oct. 18,2017

Accepted: Oct. 28, 2017

\begin{abstract}
Wadi Surd is one from the largest and important wadis in the south-western side of Sinai Peninsula due to its promising soils and water potentialities. The current work aims at study the geomorphology, Pedology and evaluation of the soils of Wadi Sudr. The geomorphological studies indicated that, there are four main geomorphologic units in the area. These units are dry Sabkha, Out wash plain, Oolitic sand and Delta plain. Ten Soil profiles were selected representing these units. The soil profiles were morphological described and samples were collected for physical and chemical analyses.

According to Soil Survey Staff (2014), the obtained results revealed that all studied soils could be categorized into order Aridisols. These soils are classified up to family level under four subgreats namely, Gypsic Haplosalids, Calcic Haplosalids, Typic Haplocalcids, Sodic Haplocalcids. The studied Soils were evaluated for their suitability for agriculture use. They categorized into two classes namely, marginally suitable (S3) and not suitable (N). These soils are suffering from limitations of texture, carbonates, gypsum, salinity and alkalinity with different intensity. The severity of these limitations could be corrected by further land improvements. Accordingly, the potential suitability of the most studied soils could be improved to moderately suitable (S2) and marginally suitable (S3). Moreover, the suitability of 11 main crops in these soils was evaluated in the current and potential situation. The results indicated that these soils are not suitable for growing these crops in the current situation. The potential suitability of the soils for these crops could be improved according to the satisfaction conditions between soil properties and crops requirements.
\end{abstract}

Key words: Geomorphic units, Soil Classification, land evaluation, suitability for agriculture.

\section{INTRODUCTION}

One of the important strategies of the Egyptian government is expanding the agricultural area, sustainable utilization of available water resources and increasing crop productivity to meet the needs of the rapid increase in population.

Sinai Peninsula is one from the important parts for agricultural expansion in Egypt. Wadi Sudr is considered as the most promising Wadi in the south western side of Sinai due to its land and water potentialities.

Location: Wadi Sudr is situated in a long axis between latitudes $29^{\circ} 30^{\prime}$ and $29^{\circ} 25^{\prime}$ North and longitudes $32^{\circ} 40^{\prime}$ and $32^{\circ} 50^{\prime}$ East. It has an area of about 625 sq.km
(150.000 feddans), Fig (1). This Wadi is about $4 \mathrm{~km}$ in width, $4-8 \mathrm{~km}$ in length and oriented roughly in an east west direction.

Climate: The studied area is characterized by a long hot rainless summer and short rainly mild winter. The maximum temperature is often exceed about $36 \mathrm{C}^{\circ}$ during summer. The average minimum temperature during the winter is about $8 \mathrm{C}^{\circ}$. The area have high evaporation rate and low relative humidity. The average evaporation rate is about $10.2 \mathrm{~mm} . \mathrm{d}^{-1}$. The relative humidity ranges between $48.2 \%$ in April and $63.5 \%$ in October. The average annual rainfall at Ras Sudr is $25.2 \mathrm{~mm}$. The actual rainy months are November to April 
with maximum rainfall in March and April (CLAC, 2014).

Geology: The surface of Wadi Surd is essentially formed of sedimentary rocks and deposits belonging to the Tertiary and Quaternary epochs. Quaternary deposits are divided into recent deposits (aeolian sand and lacustrine deposits); Plestocene deposits (crust formations that are composed of calcareous sand of marine origin and dry Sabkha as adjacent to the Oolitic dunes. Tertiary deposits are differentiated into Pliocene deposits (clays and sands); Upper Miocene deposits (coarse sands and gravels with thin clay and carbonate intercalations), Middle Miocene (argillaceous limestone with shale and marl in terbeds), and Lower Miocene (marl and sandstone fossiliferour, Carbonate in the lower part and yellow marly limestone and conglomeratic of base), El-Shazly et al., 1974; Dames and Moore, 1985; Said 1990 and Geological Survey of Egypt, 1994.

Geomorphology: Hammad (1980) and Dames and Moore (1985) reported that, Wadi Sudr embodies broadly five distinct geomorphic units namely, mountains and escarpment, present channels, terraces, deltaic plains, coastal formation and outwash plain.

Water supply: The underground water is considered the main source of water supply in Wadi Sudr. It exist in several aquifers, namely bsament rocks, Nubian sandstones and Quaternary deposits. (Dames and Moore, 1985).

This work was performed to study the geomorphology and pedology of Wadi Sudr soils. Land evaluation and its suitability for growing certain crops were also achieved in the current and potential situations.

\section{MATERIALS AND METHODS Image interpretation:}

Geomorphic map of the studied area $($ Fig, 1$)$ was produced using digital image processing of Land Sat ETM image (Path/Row, 176/39) dated 2010 and topographic maps (scale 1:20000). Arc GIS 10.4 and ERDAS imagine 8.7 software were used to produce the geomorphic map. The DEM was generated from digitized data of contour line in the topographic maps and spots hights recorded by GPS using Arc GIS software. These procedures were carried out according to Dobos et al. (2002).

Ten soil profiles were chosen representing the main geomorphic units of the studied area and 60 minipits were carried out to check the accuracy of geomorphic boundary Fig (2).

The soil profiles were morphologically described according to FAO (2006). Samples were collected from profiles according to the vertical variations. The soil samples were air dried, crushed and sieved to get the fine earth fractions $(<2 \mathrm{~mm})$. These fractions were analyzed to determine their physical and chemical characteristics according to Burt (2004). The morphological features and characteristics data are presented in Tables (1 and 2).

The studied soils were classified up to family level according to Soil Survey Staff (2014).

The evaluation of land suitability for irrigated agriculture was performed according to Sys and Verheye (1978). Also, the suitability of the studied soils for growing eleven crops were achieved according to Sys et al., (1993).

\section{RESULTS AND DISCUSSION Geomorphology of the study area:}

The geomorphic mapping units (Fig., 2) were identified on the bases of the DEM value map results. The geomorphic map interpretation indicated that, the investigated area includes 8 geomorphic units namely, Delta plain, Dry Sabkha, Lower terraces, Upper terraces, Oolitic sand, Out Wash Plain, Ridges and Escarpment (Fig., 2). The main four studied geomorphic units in this work were dry sabkha, Out Wash plain, Oolitic sand and Delta plain. 


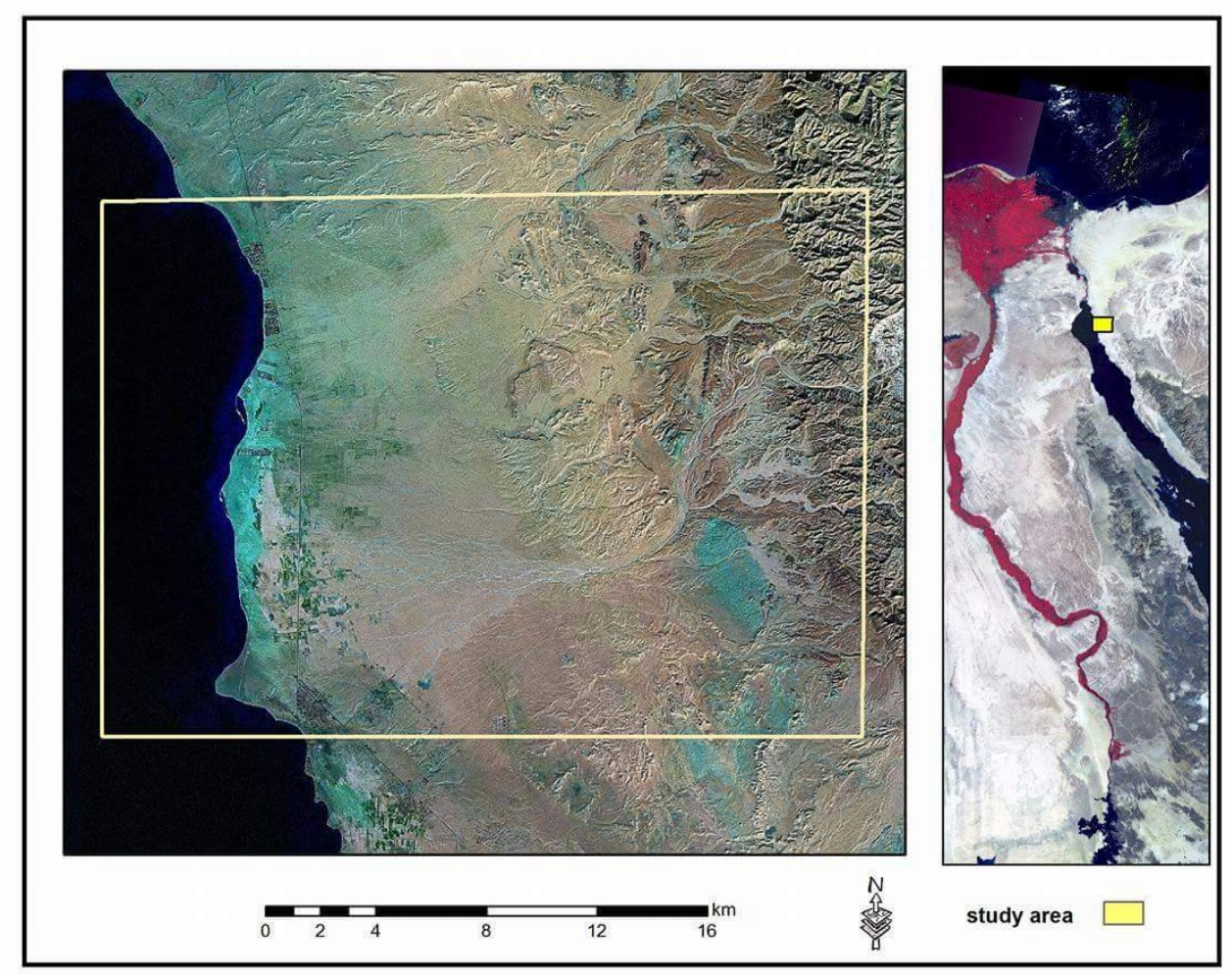

Fig. (1): Location of the study ar Fig. (2): Geomorphic Units and profiles locations of

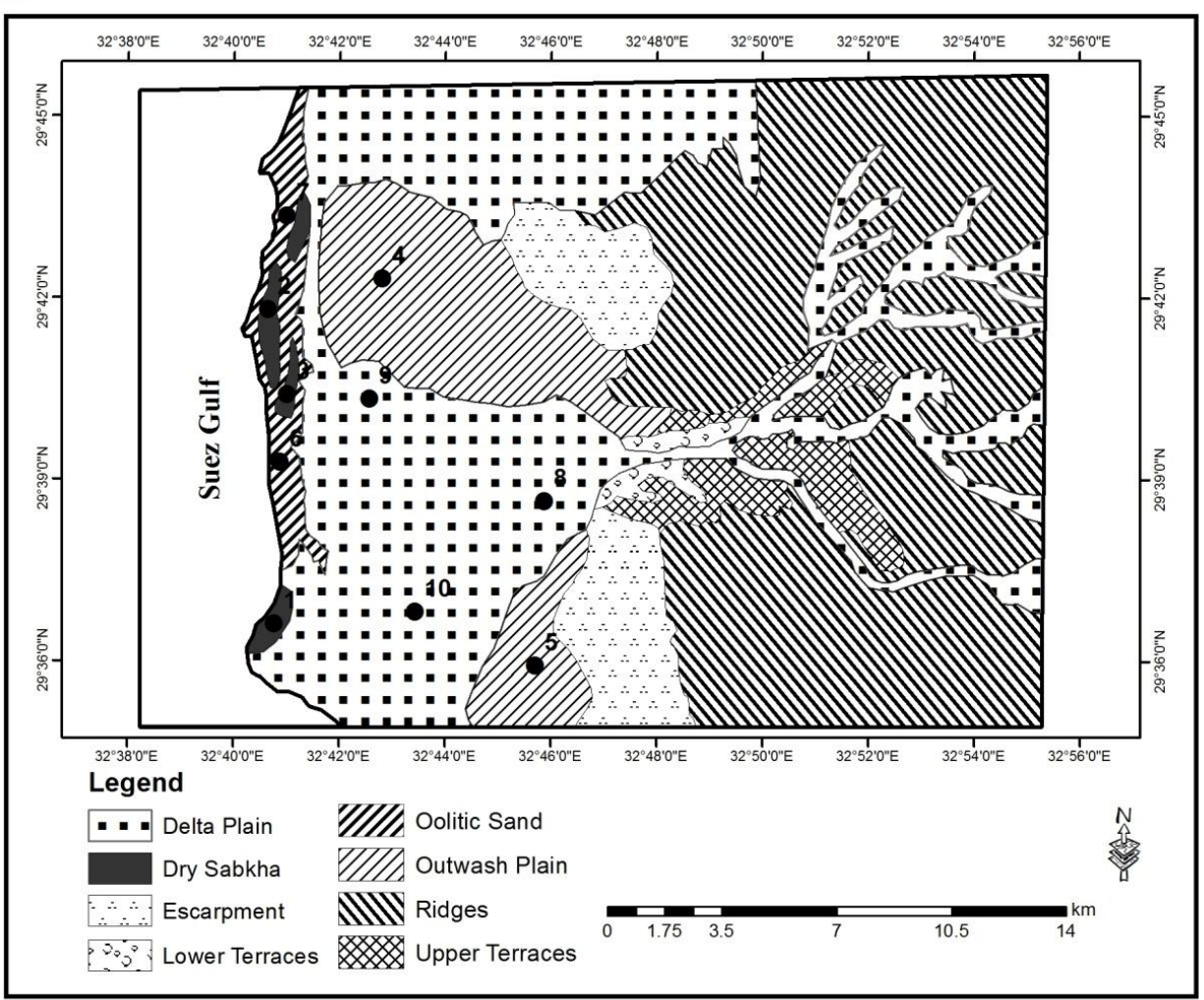


M.M. Soliman, et al.,

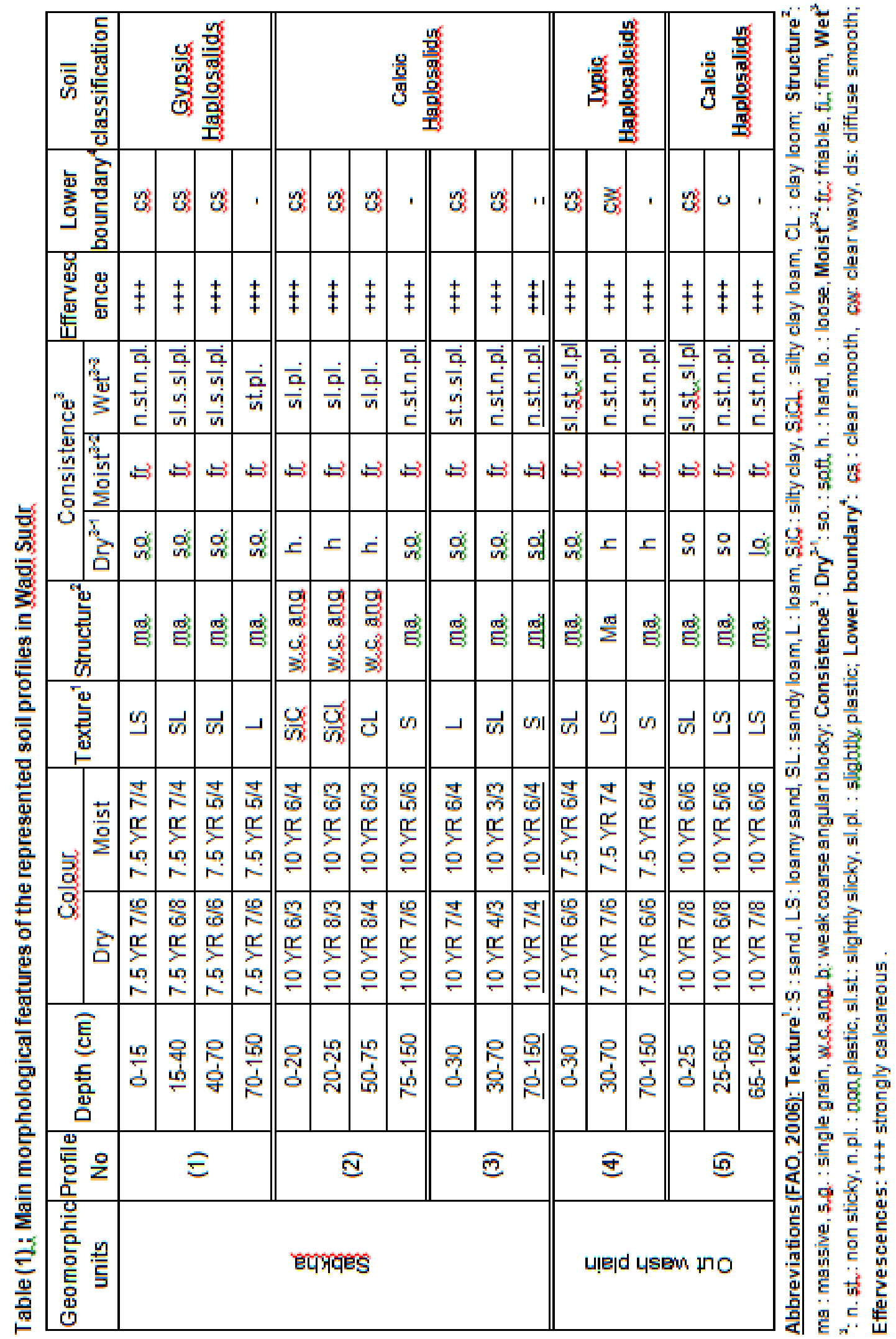


M.M. Soliman, et al.,

\begin{tabular}{|c|c|c|c|c|c|c|c|c|c|c|c|c|c|c|c|c|c|}
\hline 离 & $\begin{array}{l}\underset{D}{\infty} \\
\stackrel{\text { T }}{\leftarrow}\end{array}$ & 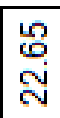 & 옹 & $\begin{array}{l}\text { กิ } \\
\text { Nิ }\end{array}$ & 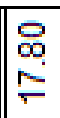 & $\stackrel{\text { N̦ }}{\grave{N}}$ & ঙั. & $\begin{array}{l}\stackrel{\circ}{\infty} \\
\stackrel{\circ}{N}\end{array}$ & 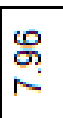 & $\begin{array}{l}\stackrel{+}{0} \\
0 \\
0\end{array}$ & $\stackrel{\stackrel{m}{m}}{\dot{v}}$ & 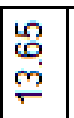 & 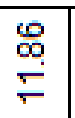 & $\stackrel{\bar{m}}{m}$ & 悐 & $\stackrel{י}{r}$ & 울 \\
\hline 岁 & 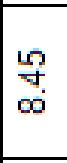 & 용 & 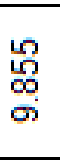 & 号 & 苜 & ণ্ণি & Ñ & $\stackrel{\bar{ஸ}}{\text { ஸे }}$ & ల్ల & $\frac{8}{\pi}$ & 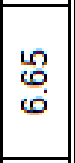 & 号 & 옥 & 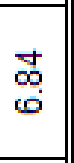 & 昌 & ํㅗ & ถึ \\
\hline 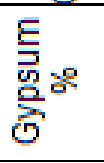 & $\begin{array}{l}\stackrel{n}{R} \\
\text { min }\end{array}$ & \begin{tabular}{l}
8 \\
\hdashline
\end{tabular} & $\begin{array}{l}\text { S } \\
\infty\end{array}$ & $\stackrel{n}{\frac{n}{0}}$ & గ్ & $\stackrel{\text { ำ }}{\circ}$ & 兄 & 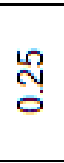 & ભ̊ & ๙ & $\stackrel{\substack{9 \\
-}}{\leftarrow}$ & 吕 & $\begin{array}{l}\stackrel{n}{N} \\
\stackrel{N}{N}\end{array}$ & 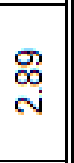 & $\hat{\text { }}$ & $\begin{array}{l}\text { Do } \\
\text { m. }\end{array}$ & స్ \\
\hline 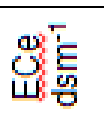 & 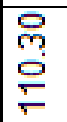 & 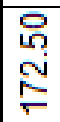 & 亗 & ণ্ & 을 & 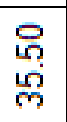 & $\begin{array}{l}\stackrel{\circ}{\circ} \\
\stackrel{\text { ஸे }}{ }\end{array}$ & $\begin{array}{l}\text { 옹 } \\
\text { เே }\end{array}$ & 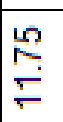 & $\stackrel{\text { mె }}{\mathrm{m}}$ & $\begin{array}{l}\overline{\text { ț }} \\
\text { 믐 }\end{array}$ & $\begin{array}{l}\text { गू } \\
\text { ले }\end{array}$ & $\stackrel{\stackrel{m}{m}}{=}$ & $\begin{array}{l}\bar{\infty} \\
\stackrel{\sim}{\leftarrow}\end{array}$ & $\begin{array}{l}\text { Uे } \\
\text { m. }\end{array}$ & 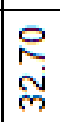 & $\begin{array}{l}\stackrel{\text { mे }}{\mathrm{N}} \\
\stackrel{\mathrm{N}}{ }\end{array}$ \\
\hline 폼 & ? & $\check{r}$ & $\stackrel{N}{N}$ & ?ִ & ? & 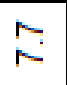 & $\stackrel{\varphi}{r}$ & $\begin{array}{l}\dot{y} \\
\infty\end{array}$ & $\underset{\infty}{\infty}$ & $\stackrel{\circ}{\sim}$ & $\stackrel{\circ}{\sim}$ & $\tau_{\infty}$ & $\stackrel{\circ}{\sim}$ & $\check{\infty}$ & $\check{\infty}^{-}$ & $N$ & 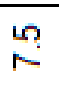 \\
\hline ¿ & N & กิ & ల్ల & 웅 & 웅 & 尔 & 号 & 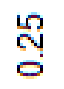 & ? & $\stackrel{ }{\circ}$ & 응 & ભొ & $\overline{\mathrm{N}}$ & $\stackrel{m}{\circ}$ & in & $\frac{\sigma}{0}$ & $\stackrel{ }{\circ}$ \\
\hline ర্তু & $\stackrel{\circ}{\circ}$ & $\begin{array}{l}\stackrel{0}{N} \\
\stackrel{m}{m}\end{array}$ & $\stackrel{\infty}{\check{\circ}}$ & है & 옹 & ్ㅗ & ָુ & 움 & 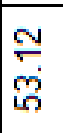 & 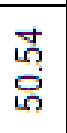 & 号 & 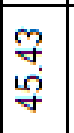 & 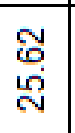 & 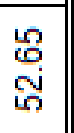 & 路 & m & $\begin{array}{l}\text { ज̃ } \\
\text { مึ }\end{array}$ \\
\hline 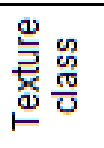 & ש & $\vec{\sigma}$ & $\vec{n}$ & 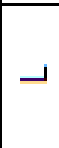 & 造 & $\overrightarrow{\bar{Q}}$ & $\overline{0}$ & $\omega$ & 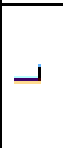 & $\vec{n}$ & $\omega$ & $\vec{n}$ & s & $\omega$ & $\vec{\omega}$ & a & ฮ \\
\hline 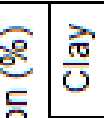 & $N$ & $\stackrel{\stackrel{\sim}{ָ}}{\leftarrow}$ & 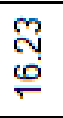 & $\begin{array}{l}\text { Oִ } \\
\stackrel{\mathrm{N}}{ }\end{array}$ & $\begin{array}{l}8 \\
8 \\
0 \\
\end{array}$ & $\begin{array}{l}\stackrel{\circ}{6} \\
\text { ले }\end{array}$ & 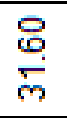 & $\begin{array}{l}\text { Ñ } \\
\text { dv }\end{array}$ & 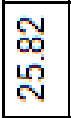 & 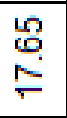 & 号 & 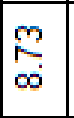 & 웃 & $\begin{array}{l}\infty \\
\dot{v}\end{array}$ & 옹 & 오ํ & $\stackrel{m}{\circ}$ \\
\hline 害 & $\begin{array}{l}\stackrel{0}{0} \\
\stackrel{0}{\circ}\end{array}$ & $\stackrel{m}{\stackrel{m}{\leftarrow}}$ & $\begin{array}{l}\text { 우 } \\
\text { ํํ }\end{array}$ & $\begin{array}{l}\text { Jे } \\
\text { ले }\end{array}$ & 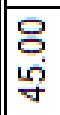 & $\begin{array}{l}\stackrel{\circ}{N} \\
\text { + }\end{array}$ & $\begin{array}{l}\text { 우 } \\
\text { ஸे }\end{array}$ & مִ & $\begin{array}{l}\text { ?ु } \\
\text { जे } \\
\text { ले }\end{array}$ & $\stackrel{ }{\check{0}}$ & $\stackrel{\circ}{\leftarrow}$ & $\begin{array}{l}\curvearrowright \\
\infty \\
\infty\end{array}$ & $\underset{\omega}{\frac{1}{0}}$ & $\stackrel{\substack{N \\
\sim}}{ }$ & m & 웜 & ָั \\
\hline 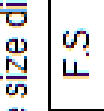 & 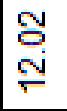 & $\begin{array}{l}\text { 웅 } \\
\text { o } \\
\text { q }\end{array}$ & $\begin{array}{l}\mathscr{p} \\
\ddot{\circ}\end{array}$ & $\begin{array}{l}\text { @o } \\
\stackrel{\circ}{\circ}\end{array}$ & \begin{tabular}{l}
8 \\
\hdashline
\end{tabular} & $\begin{array}{l}\text { ㅁ } \\
\stackrel{\text { N }}{ }\end{array}$ & 尔 & 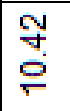 & 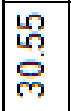 & $\stackrel{\circ}{\stackrel{一}{m}}$ & $\stackrel{\infty}{\frac{\infty}{6}}$ & 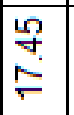 & $\begin{array}{l}\text { 웅 } \\
\text { 움 }\end{array}$ & 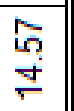 & 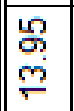 & \begin{tabular}{|l|} 
\\
$\infty$ \\
\\
\end{tabular} & $\begin{array}{l}\text { ळ } \\
\text { के }\end{array}$ \\
\hline 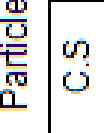 & 告 & ले & $\begin{array}{l}\bar{\sigma} \\
\stackrel{ }{ }\end{array}$ & 웅 & 움 & $\begin{array}{l}\circ \\
\infty \\
\oplus\end{array}$ & ભ̊ & $\begin{array}{l}\stackrel{2}{2} \\
\stackrel{2}{\circ} \\
\stackrel{\infty}{\infty}\end{array}$ & $\begin{array}{l}\text { ํ. } \\
\infty\end{array}$ & $\begin{array}{l}\text { ? } \\
\text { ơ }\end{array}$ & 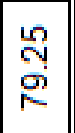 & $\begin{array}{l}8 \\
\text { ํ. } \\
\text { เి }\end{array}$ & $\stackrel{n}{\stackrel{n}{\sigma}}$ & 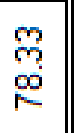 & $\frac{n}{\stackrel{n}{r}}$ & 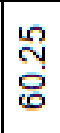 & $\begin{array}{l}\text { o } \\
\text { in } \\
\text { م. }\end{array}$ \\
\hline$\frac{\frac{\omega n}{\omega}}{\overbrace{0}^{\frac{\omega}{0}}}$ & $\sim$ & $\sim$ & $\sim$ & $\sim$ & ما & $N$ & $\sim$ & n & $\sim$ & in & n & مo & 은 & 움 & $\sim$ & 은 & 은 \\
\hline $\begin{array}{l}\text { 호응 } \\
\text { 응 }\end{array}$ & $\frac{n}{1}$ & $\begin{array}{l}\text { 움 } \\
\text { ñ }\end{array}$ & 웅 & 음 & ণ্ণি & 웅 & 足 & 点 & প্ & 웅 & $\frac{0}{\text { 음 }}$ & প্লি & 웅 & $\frac{\circ}{\stackrel{5}{c}}$ & $\stackrel{\leftrightarrow}{\sim}$ & 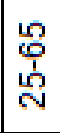 & 웅 \\
\hline 旁 & \multicolumn{4}{|c|}{ 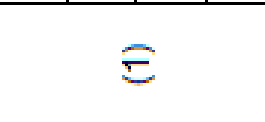 } & \multicolumn{4}{|c|}{$\widehat{d}$} & \multicolumn{3}{|c|}{ ๓ุ } & & త & & \multicolumn{3}{|c|}{$\sqrt{2}$} \\
\hline 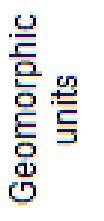 & \multicolumn{11}{|c|}{ еप्ववes } & \multicolumn{6}{|c|}{ ulejd usemie } \\
\hline
\end{tabular}




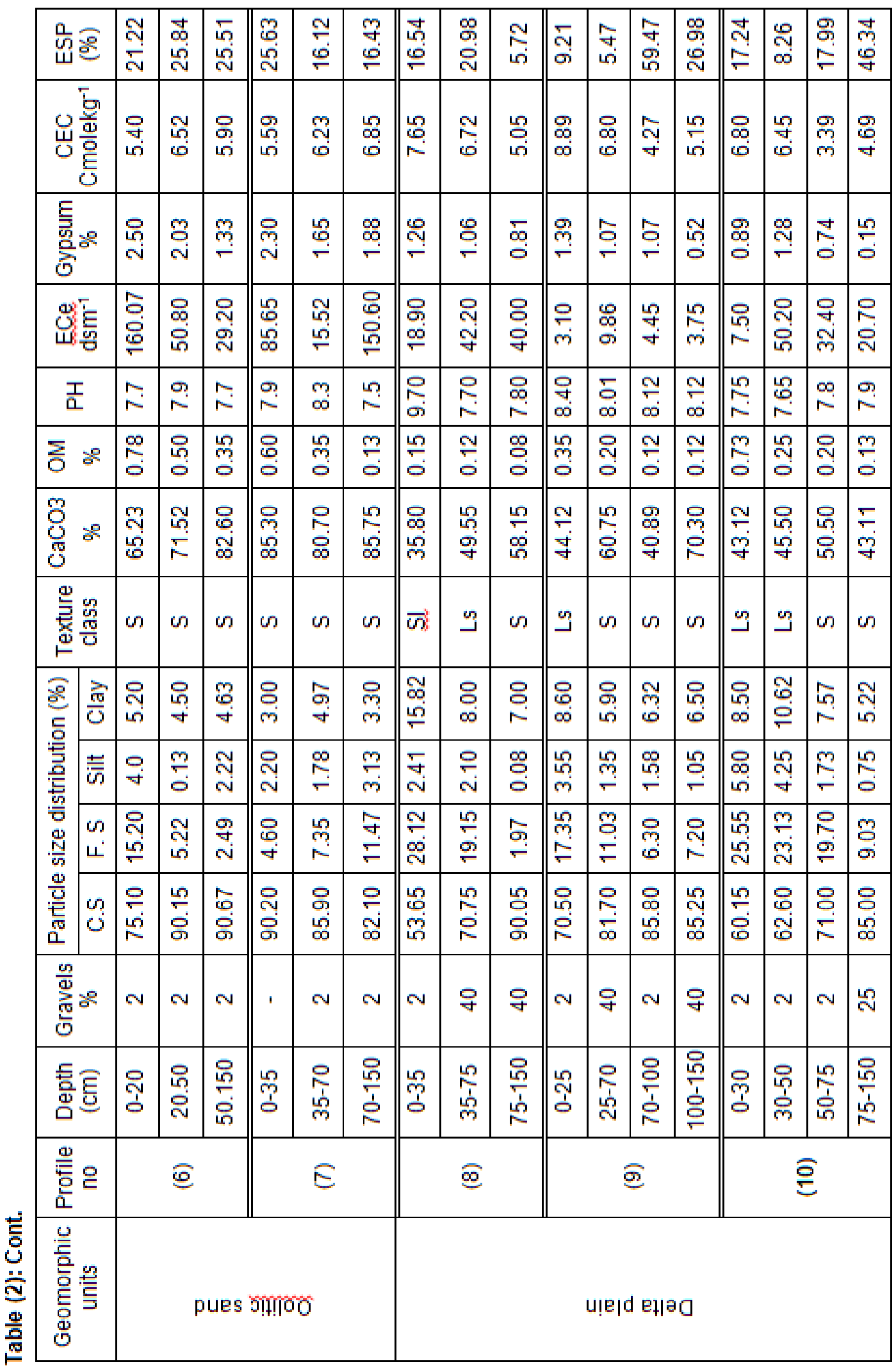




\section{Soil characteristics:}

The morphological description of soil profiles and samples representing the studied geomorphic units in the studied area are presented in Table (1). The physicochemical properties of these profiles are shown in Table (2). Characteristics of the soils representing each of studied geomorphic units can be disputed as follows.

\section{Soils of dry Sabkha}

This unit is located in the western side of the studied area. The soils of this unit are represented by three soil profiles $(1,2$ and 3 ). Topography of the landscape is almost flat to slightly undulating. The soil colour varied from brown (10 YR 4/3) to very pale brown (10 YR8/4) in dry status. Moist colour ranged from light brown (10YR 6/3) to brown (7.5 YR 5/4). Texture of the soils representing with profiles I and 3 varied from sand to sandy loam. The texture of profile 2 varied between silty clay and clay loam in the upper layer changed to sand in the deepest one. These soils have 2 to $5 \%$ fine and medium gravels. Soil consistence varied from soft to hard (dry) and friable (moist). The soils are highly calcareous as indicated by calcium carbonate content which varied from 35.76 to $70.7 \%$ without distribution pattern with depth. Organic matter content is very low $(<0.72 \%)$.

Soil reaction are generally neutral to moderately alkaline which the $\mathrm{pH}$ values ranged from 7.1 to 8.4. The soils are nonsaline to very extremely saline as indicated by ECe values, that ranged from 1.75 to $172.5 \mathrm{dsm}^{-1}$. Gypsum content varied from 0.15 to $8.9 \%$.

Cation exchange capacity coincided with soil texture, and varied from 5.9 to 20.3 Cmole $\mathrm{kg}^{-1}$. Exchangeable Sodium Percentage (ESP) values of profiles 1 and 2 are more than $15 \%$ indicating sodicity effect. While it is $<15 \%$ in profile 3 indicating non sodic soils.

\section{Soils of out wash plain}

This unit is located in the north and south parts of the study area close to the faulted escarpments of the sedimentary rock structure. The sediments are transported and deposited by torrential streams. The soils of this unit are represented by profiles 4 and 5 (Tables 1and 2). Topography is gently undulating and gently sloping towards the west. The surface is covered with many gravels and few stones. Soil colour is yellow (10YR 7/8) to reddish yellow (7.5 YR 7/6) dry and yellowish brown (10 YR 5/8) to pink (7.5YR7/4) moist. Soil texture is slightly gravelly sandy loam in the surface changed to extremely gravelly loamy sand with soil depth.

Soil structure is generally massive or single grains. Consistence varied from soft or hard dry to friable moist.

Calcium carbonate content ranged from 22.62 to $55.24 \%$ without specific pattern with soil depth. Organic matter and gypsum contents were $<0.51 \%$ and $<3.07 \%$, respectively. The soils are slightly to moderately alkaline $(\mathrm{pH}$ between 7.5 and 8.1), They are slightly saline to extremely saline, (ECe between 3.64 and $32.70 \mathrm{dsm}^{-1}$ ). CEC ranged between 6.5 and 11.5 Cmole $\mathrm{kg}^{-1}$. ESP varied from $3.31 \%$ to $13.68 \%$ indicating non sodicity effect.

\section{Soils of Oolitic sand}

This unit includes coastal forms, that are mainly deposited under the sea and wind actions. These sediments occupy a narrow strip of complex pattern along the shoreline of Red Sea coastal plain and Suez Gulf. This pattern is dominated by beaches, covered with over blown sand and scattered natural vegetation.

The soil surface is almost flat or nearly level. This geomorphic unit is represented by profiles 6 and 7. Data in Tables (1 and 2) indicate that, soil colour varied from reddish yellow (7.5 YR 7/8) to pink (7.5 YR 7/3) dry and light brown (7.5YR 6/4) to reddish 
brown (7.5 YR 7/4) moist. These soils have sandy texture throughout the entire profiles depths. They are extremely calcareous having $65.23 \%$ to $85.75 \% \mathrm{CaCO}_{3}$. Organic matter and gypsum contents ranged from 0.13 to $0.78 \%$ and 1.33 to $2.5 \%$, respectively. They are slightly to moderately alkaline (PH 7.7 to 8.3). The soils are moderately saline to very extremely saline having ECe values between 15.52 and $160.7 \mathrm{dsm}^{-1}$. Cation exchange capacity was very low and differ from 5.4 to 6.85 Cmole $\mathrm{kg}^{-1}$. ESP varied from 16.12 to $25.84 \%$ indicating that, these soils have sodicity effect.

\section{Soils of Delta plain}

Delta plain unit and their tributaries are found in the middle of the study area at the lowest level of Wadi Sudr. It extends from the limestone rocks highland eastwards to the Red Sea and the Gulf of Suez westwards.

It is filled with alluvial material formed by weathering factors on the parent rocks and transported by flood water to the lowlands. It is represented by three soil profiles 8,9 and 10.

Data in Tables (1 and 2) revel that soil colour is yellow (10YR8/6) to reddish yellow (7.5 YR 6/6) dry and brownish yellow (10YR6/6) to light brown (7.5 YR6/4) moist. The soils have sand to sandy loam texture and single grains to massive structure. These soils contain 2 to $40 \%$ fine to medium gravels and few stones. Calcium carbonate content is very high and differ from 35.8 to $70.3 \%$ without specific pattern with depth, It tends to increase with depth in profile 8 . Organic matter and gypsum contents not exceeds $0.43 \%$ and $1.39 \%$, respectively. The soils are slightly to moderately alkaline $(\mathrm{PH} 7.65$ to 8.4$)$. They are very slightly saline to extremely saline (ECe ranged from 3.1 to $\left.50.2 \mathrm{dsm}^{-1}\right)$. CEC ranged from 3.39 to

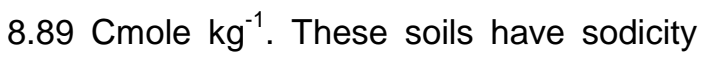
effect (ESP $>15 \%)$.

\section{Soil classification}

The studied soils are classified according to the diagnostic criteria of Soil Survey Staff (2014). Based on the prevailing climatic conditions, morphological features, and analytical data of these soils, they classified under Aridisols order (Table, 3). These soils have an Ochric epipedon and one or more from the diagnostic horizons of Salic, Calcic, Sodic and Gypsic. Therefore, the soils are classified up to family level under four subgreat groups namely, Gypsic Haplosalids (profile, 1), Calcic Haplosalids (profiles, 2, 3, 5, 6, 7, 8 and 10), Typic Haplocalcids (profile 4) and Sodic Haplocalcids (profile, 9) as shown in Table (3).

\section{Land Evaluation:}

\section{Evaluation of land suitability for irrigated agriculture}

Quantitative estimation of soil characteristics were used for evaluation land suitability index according to Sys and Verhey (1978). The soil characteristics used were topography, wetness, texture, soil depth, $\mathrm{CaCO}_{3}$, gypsum and salinity and alkalinity. Classification of the soils to suitability grades was applied according to their calculated suitability indexes (Ci) as the following criteria:

\begin{tabular}{|c|c|c|c|}
\hline $\begin{array}{c}\mathbf{C i} \\
(\%)\end{array}$ & Order & Class & Soil grades \\
\hline $\begin{array}{l}75- \\
100 \\
\end{array}$ & \multirow[t]{3}{*}{ S } & S1 & Highly suitable \\
\hline $\begin{array}{l}50- \\
<75\end{array}$ & & S2 & $\begin{array}{l}\text { Moderately } \\
\text { suitable }\end{array}$ \\
\hline $\begin{array}{l}25- \\
>50\end{array}$ & & S3 & $\begin{array}{l}\text { Marginally } \\
\text { suitable }\end{array}$ \\
\hline$<25$ & $\mathrm{~N}$ & $\mathrm{~N}$ & Not suitable \\
\hline
\end{tabular}

Suitability indexes ( $\mathrm{Ci}$ ) of the studied soils were calculated for their current (Cs) and potential situations (Ps) as shown in Table (4). 
M.M. Soliman, et al.,

Table (3): Classification of the studied soils according to Soil Survey Staff (2014).

\begin{tabular}{|c|c|c|c|}
\hline \multirow{2}{*}{ Geomorphic Unit } & \multirow{2}{*}{ Profiles } & \multicolumn{2}{|r|}{ classification } \\
\hline & & Sub-great group & Family \\
\hline \multirow{3}{*}{ Sabkha } & 1 & Gypsic Haplosalids & $\begin{array}{l}\text { Coarse loamy over fine clay, } \\
\text { carbonatic, hyperthermic }\end{array}$ \\
\hline & 2 & \multirow{2}{*}{ Calcic Haplosalids } & $\begin{array}{l}\text { Fine silty over sandy, carbonatic, } \\
\text { hyperthermic }\end{array}$ \\
\hline & 3 & & $\begin{array}{l}\text { Coarse loamy over sandy, } \\
\text { carbonatic, hyperthermic }\end{array}$ \\
\hline \multirow{2}{*}{ Out wash plain } & 4 & Typic Haplocalcids & $\begin{array}{l}\text { Sandy-skeletal, carbonatic, } \\
\text { hyperthermic }\end{array}$ \\
\hline & 5 & Calcic Haplosalids & $\begin{array}{l}\text { Sandy-skeletal, carbonatic, } \\
\text { hyperthermic }\end{array}$ \\
\hline Oolitic plain & 6 and 7 & \multirow{2}{*}{ Calcic Haplosalids } & Sandy, carbonatic, hyperthermic \\
\hline \multirow{2}{*}{ Deltaic plain } & 8 and 10 & & $\begin{array}{l}\text { Sandy-skeletal, carbonatic, } \\
\text { hyperthermic }\end{array}$ \\
\hline & 9 & Sodic Haplocalcids & $\begin{array}{l}\text { Sandy-skeletal, carbonatic, } \\
\text { hyperthermic }\end{array}$ \\
\hline
\end{tabular}

\section{Current Suitability}

Data in Table (4) indicated that the soils represented the studied geomorphic unit were placed into two suitability classes and grades namely, marginally suitable (S3) and non-suitable (N), Fig. (3).

\section{Marginally suitable soils (S3):}

These soils have suitability index (Ci) values ranged from 30.38 to $35.10 \%$. These are the soils of profiles 2,3 (Sabkha), and 4,5 (out wash plain). The soils have a moderate intensity of texture, calcium carbonate and salinity \& alkalinity limitations.

\section{Non suitable soils (N1):}

These soils have suitability index (Ci) values varied from 10.8 to $23.4 \%$. These are the soils profiles 1 (sabkha); 6 and 7 (Oolitic sand); 8, 9 and 10 (delta plain). These soils have a severe intensity of salinity and alkalinity, moderate to severe intensity of $\mathrm{Ca} \mathrm{CO}_{3}$ and texture limitations.

\section{Potential land suitability:}

Further land improvements are required to correct or reduce the severity of soil limitations exiting in the studied area. These improvements are such as leaching of salts, addition of organic and conditioners amendments as well as applying of modern irrigation systems. Accordingly, the potential suitability evaluation of the most studied soils could be upgrade to the following grades as shown in Table (4) and Fig. (4).

\section{Moderately suitable soils (S2)}

This grade has the soils of Sabkha (profiles 1 and 2) with potential suitability index value $(52 \%)$.

\section{Marginally suitable soils (S3)}

This grade has the soils of sabkha (profile 3), outwash plain (profiles 4 and 5), Oolitic sand (profile 6) and Delta plain, (profiles 8, 9 and 10). Potential Suitability index (Ps) values are varied from $27 \%$ to $49 \%$.

The soils of Oolitic sand (profile 7) are still non-suitable (N2) having Ci value of $24.0 \%$. These soils have a severe intensity of texture and moderate intensity of calcium carbonate limitations. 


\begin{tabular}{|c|c|c|c|c|c|c|c|c|c|c|c|}
\hline \multirow{2}{*}{$\begin{array}{l}\text { 岁 } \\
\text { 总 }\end{array}$} & $\underset{q}{q}$ & กี & กี & $\mathscr{E}$ & $\mathscr{B}$ & $\mathscr{H}$ & $\mathscr{B}$ & $z$ & $\mathscr{Z}$ & $\mathscr{B}$ & $\tilde{E}$ \\
\hline & 3 & $\bar{z}$ & $\mathcal{B}$ & $\mathscr{Z}$ & $\mathcal{B}$ & $\mathscr{B}$ & $\bar{z}$ & $\bar{z}$ & $\bar{z}$ & $\bar{z}$ & $\bar{z}$ \\
\hline \multirow{2}{*}{ 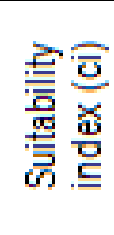 } & $\bar{\alpha}$ & $\begin{array}{l}8 \\
\text { กิ่ }\end{array}$ & $\begin{array}{l}8 \\
\text { ஸิ }\end{array}$ & $\begin{array}{l}8 \\
\text { 寸 }\end{array}$ & $\begin{array}{l}\text { 怘 } \\
\text { 字 }\end{array}$ & $\begin{array}{l}\text { 号 } \\
\stackrel{9}{9}\end{array}$ & 8 & \begin{tabular}{l}
8 \\
\multirow{2}{*}{}
\end{tabular} & $\begin{array}{l}8 \\
\text { Oे }\end{array}$ & $\begin{array}{l}8 \\
\text { e্ল }\end{array}$ & $\begin{array}{l}\text { 유 } \\
\stackrel{9}{9}\end{array}$ \\
\hline & $\overline{0}$ & 昌 & 응 & 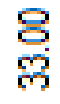 & 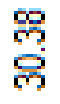 & 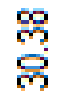 & 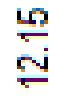 & 오 & $\begin{array}{l}8 \\
\infty \\
\infty\end{array}$ & $\begin{array}{l}\text { ్ㅗ } \\
\text { co }\end{array}$ & 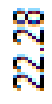 \\
\hline \multirow{2}{*}{ 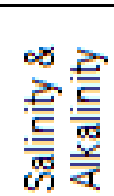 } & $\bar{\alpha}$ & 8 & 음 & 음 & 응 & 응 & 음 & 응 & 음 & 음 & 8 \\
\hline & $\overline{0}$ & 里 & $\ddot{r}$ & $\ddot{r}$ & $\stackrel{2}{2}$ & $\ddot{2}$ & 过 & 过 & 过 & 果 & 过 \\
\hline \multirow{4}{*}{ 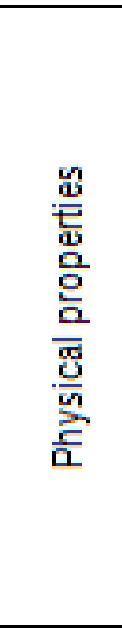 } & $\begin{array}{l}\text { 통 } \\
\text { 긍 } \\
\text { ․ }\end{array}$ & 응 & 8 & 음 & 은 & 음 & 8 & 음 & 음 & 8 & 8 \\
\hline & $\begin{array}{l}\text { ర్ } \\
\text { ర్ల్ }\end{array}$ & ৪ & $\infty$ & $\infty$ & 8 & 8 & 8 & $\infty$ & $\varnothing$ & வ & 8 \\
\hline & $\begin{array}{l}\text { 들 } \\
\text { 흠 } \\
\overline{\bar{\circ}} \\
\text { o }\end{array}$ & 음 & 음 & 음 & 8 & 음 & 음 & 음 & 음 & 음 & 음 \\
\hline & 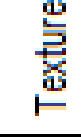 & 18 & 용 & 용 & 过 & 过 & লি & লি & 웅 & 웅 & 㟔 \\
\hline \multirow{2}{*}{ 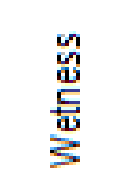 } & $\bar{\alpha}$ & 음 & 음 & 음 & 은 & 음 & 음 & 음 & 음 & 음 & 음 \\
\hline & $\overline{0}$ & 8 & 8 & 8 & 8 & 8 & 8 & 음 & 8 & 8 & 8 \\
\hline \multirow{2}{*}{ 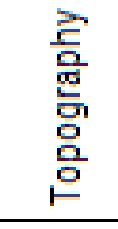 } & $\bar{q}$ & 8 & 8 & 8 & 8 & 8 & 8 & 8 & 은 & 은 & 음 \\
\hline & ن & 8 & 8 & 8 & 8 & 음 & 음 & 음 & 8 & 은 & 은 \\
\hline \multicolumn{2}{|c|}{ 岂 } & - & $\sim$ & $m$ & $\forall$ & $\omega$ & $\omega$ & $r$ & $\infty$ & $\sigma$ & 으 \\
\hline \multicolumn{2}{|c|}{ 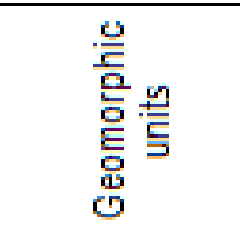 } & \multicolumn{3}{|c|}{ 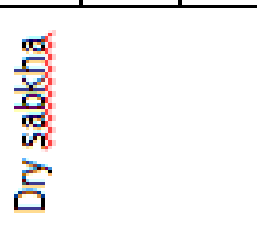 } & \multicolumn{2}{|l|}{ 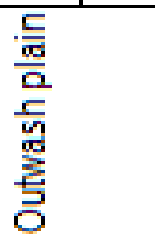 } & \multicolumn{2}{|c|}{ 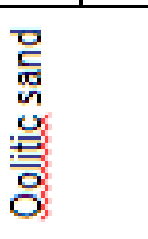 } & \multicolumn{3}{|l|}{ 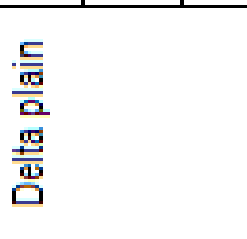 } \\
\hline
\end{tabular}




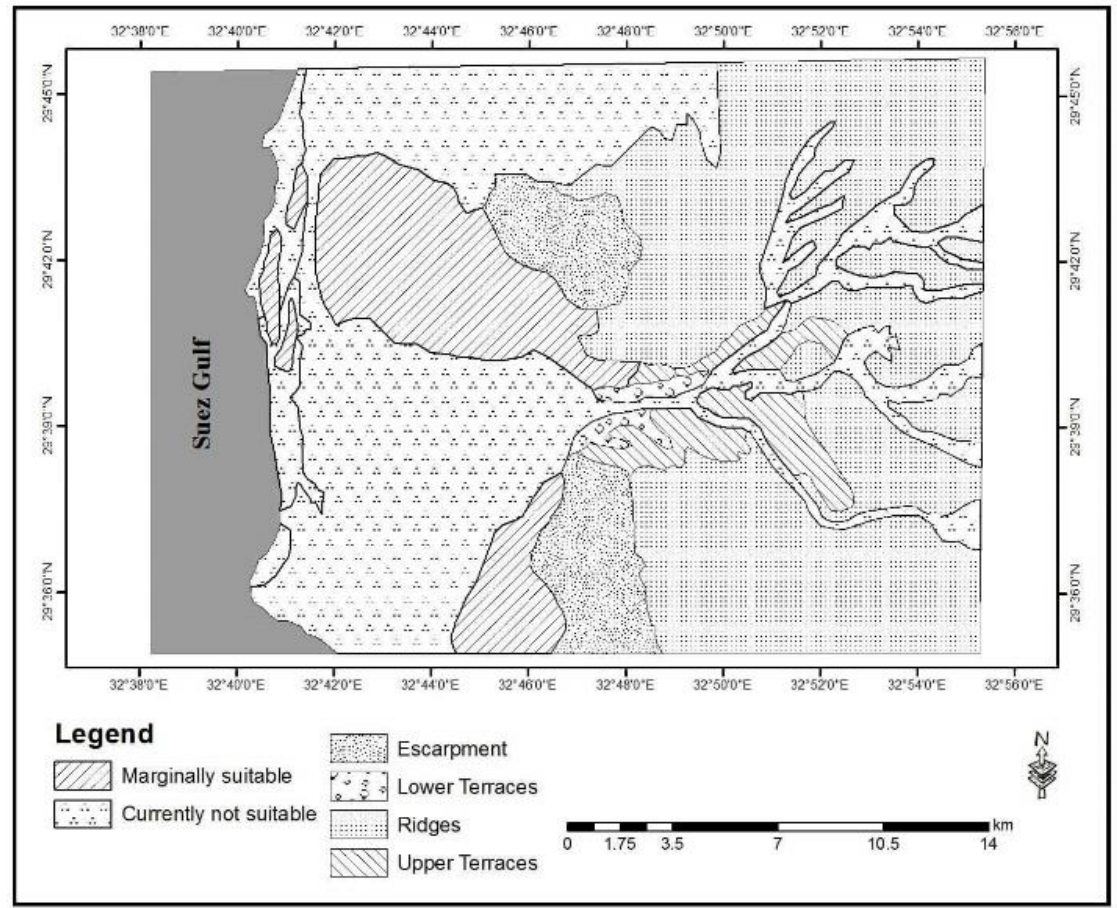

Fig. (3): Current Soil suitability for irrigated agriculture of the studied area.

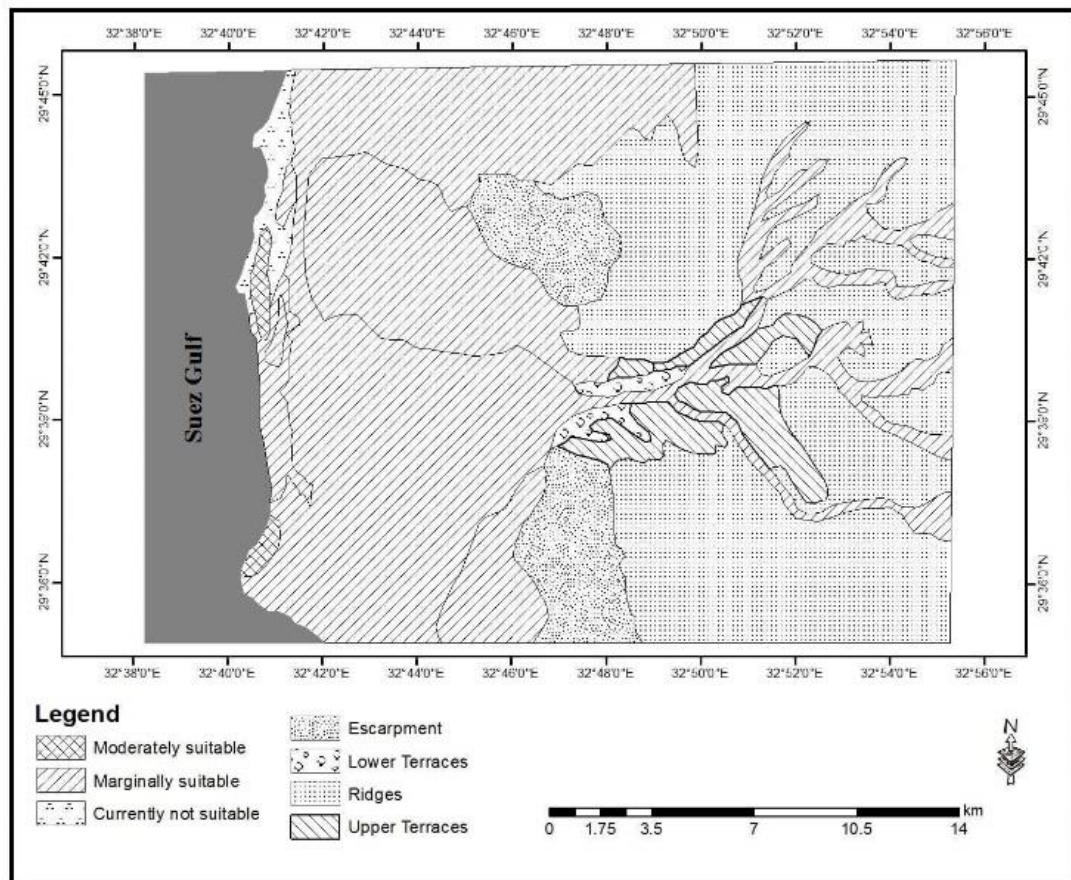

Fig. (4): Potential Soil suitability for irrigated agriculture of the studied area. 


\section{Evaluation of land suitability for growing some main crops}

Eleven main field, vegetable and fruit crops were selected to predict their suitability for cultivation in the current and potential situation of the studied soils according to Sys et. al. (1993). The obtained data are presented in Table (5).

\section{1- Current suitability for growing crops:}

Data in Table (5) revealed that, all the studied soils are not suitable $(\mathrm{N})$ for growing all the studied corps.

\section{2- Potential suitability for growing crops:}

After verifying, the aforementioned land improvements, the potential suitability of the studied soils for growing studied main crops can be explained as follows, Table (5).

a- Soils of sabkha are marginally suitable (S3) for maize, wheat, barley, sunflower, alfalfa, onion, palm and olives. Whereas they are not suitable $(\mathrm{N})$ for tomato, citrus and mango.

b- Soils of out wash plain are moderately suitable (S2) for plam and olives. They are marginally suitable (S3) for maize, wheat, barley, sunflower, alfalfa, onion, tomato, citrus and mango.

Table (5): Ratings and classes of soil suitability for growing main crops in the soils of studied geomorphic units.

\begin{tabular}{|c|c|c|c|c|c|c|c|c|c|c|c|c|c|c|c|c|}
\hline \multirow{2}{*}{$\begin{array}{l}\text { Certain } \\
\text { crops }\end{array}$} & \multicolumn{4}{|c|}{ Sabkha } & \multicolumn{4}{|c|}{ Outwash plain } & \multicolumn{4}{|c|}{ Oolitic sand } & \multicolumn{4}{|c|}{ Delta plain } \\
\hline & ${ }^{1} \mathrm{Ci}$ & ${ }^{2} \mathrm{Cs}$ & ${ }^{3} \mathrm{Pi}$ & ${ }^{4} \mathrm{Ps}$ & $\mathrm{Ci}$ & Cs & $\mathrm{Pi}$ & Ps & $\mathrm{Ci}$ & Cs & $\mathrm{Pi}$ & Ps & $\mathrm{Ci}$ & Cs & $\mathrm{Pi}$ & Ps \\
\hline & \multicolumn{16}{|c|}{ Field crops } \\
\hline Maize & 5.35 & $\mathrm{~N}$ & 48.32 & S3 & 4.86 & $\mathrm{~N}$ & 40.51 & S3 & 2.50 & $\mathrm{~N}$ & 36.70 & S3 & 12.45 & $N$ & 55.31 & S2 \\
\hline Wheat & 4.85 & $\mathrm{~N}$ & 35.92 & S3 & 5.54 & $\mathrm{~N}$ & 30.4 & S3 & 3.62 & $\mathrm{~N}$ & 33.41 & S3 & 6.12 & $\mathrm{~N}$ & 50.16 & S2 \\
\hline Barley & 3.26 & $\mathrm{~N}$ & 29.72 & S3 & 4.17 & $N$ & 30.6 & S3 & 4.66 & $\mathrm{~N}$ & 36.35 & S3 & 14.32 & $N$ & 51.72 & S2 \\
\hline Sunflower & 3.35 & $\mathrm{~N}$ & 38.51 & S3 & 6.14 & $\mathrm{~N}$ & 40.91 & S3 & 4.22 & $N$ & 27.92 & S3 & 10.54 & $N$ & 52.35 & S2 \\
\hline \multirow[t]{2}{*}{ Alfalfa } & 5.39 & $\mathrm{~N}$ & 45.5 & S3 & 3.15 & $\mathrm{~N}$ & 47.81 & S3 & 5.91 & $N$ & 42.32 & S3 & 8.16 & $\mathrm{~N}$ & 51.15 & S2 \\
\hline & \multicolumn{16}{|c|}{ Vegetable crops } \\
\hline Onion & 2.55 & $\mathrm{~N}$ & 29.30 & S3 & 6.19 & $\mathrm{~N}$ & 42.51 & S3 & 3.91 & $N$ & 25.6 & S3 & 5.55 & $\mathrm{~N}$ & 57.92 & S2 \\
\hline \multirow[t]{2}{*}{ Tomato } & 1.88 & $\mathrm{~N}$ & 1244 & $\mathrm{~N}$ & 8.82 & $\mathrm{~N}$ & 37.9 & S3 & 2.35 & $N$ & 15.23 & $N$ & 7.82 & $\mathrm{~N}$ & 52.18 & S2 \\
\hline & \multicolumn{16}{|c|}{ Fruit trees } \\
\hline Citrus & 3.26 & $\mathrm{~N}$ & 15.85 & $\mathrm{~N}$ & 5.81 & $\mathrm{~N}$ & 41.32 & S3 & 2.24 & $N$ & 16.72 & $N$ & 4.29 & $\mathrm{~N}$ & 49.31 & S3 \\
\hline Mango & 2.75 & $\mathrm{~N}$ & 15.66 & $\mathrm{~N}$ & 4.54 & $\mathrm{~N}$ & 39.91 & S3 & 3.78 & $N$ & 28.8 & S3 & 8.90 & $\mathrm{~N}$ & 52.62 & S2 \\
\hline Palm & 10.12 & $\mathrm{~N}$ & 40.35 & S3 & 22.51 & $\mathrm{~N}$ & 60.71 & S2 & 9.11 & $\mathrm{~N}$ & 30.12 & S3 & 14.82 & $\mathrm{~N}$ & 48.22 & S3 \\
\hline Olives & 10.02 & $\mathrm{~N}$ & 49.30 & S3 & 8.13 & $\mathrm{~N}$ & 65.62 & S2 & 4.51 & $\mathrm{~N}$ & 39.95 & S3 & 9.45 & $\mathrm{~N}$ & 52.62 & S2 \\
\hline
\end{tabular}

${ }^{1} \mathrm{Ci}=$ Current index, ${ }^{2} \mathrm{Cs}=$ Current suitability, ${ }^{3} \mathrm{Pi}=$ Potential, index, ${ }^{4} \mathrm{Ps}=$ Potential suitability. 
c- Soils of Oolitic sand are marginally suitable (S3) for maize, wheat, barley, sunflower, alfalfa, onion, mango, palm and olive. These soils are not suitable (N) for tomato and citrus.

d- Soils of Delta plain are moderately suitable (S2) for maize, wheat, barely, sun flower, alfalfa onion, tomato, mango and olives. These soils are marginally suitable (S3) for citrus and palm.

\section{REFERENCES}

Burt, Rebecca. Ed., (2004). Soil Survey Laboratory Methods Manual, Soil Survey Investigations Report No. 42, Version 4, USDA, NRES, Lincoln, Nebraska.

CLAC (2014). Central Laboratory for Agriculture Climate, Ministry of Agriculture Climatic elements from El-Tor station (2010-2014).

Dames and Moore (1985). Agriculture and Fisheries Sinai development study: plase 1. Report submitted to the Ministry of Development, Egypt.

Dobos, E., B. Norman, W. Bruse, M. Lnca, J. chris and M. Erika (2002). The use of DEM and satellite images for Regional Scale. Soll Database, $17^{\text {th }}$ World Congress of Soil Science (Wcss), 14-21 August 2002, Bangkak, Thailand

El-Shazly-E.M., M. A. Abdel Hady, M. A. ElGhawaby, I. A. El-Kassas and M. M. ElShazly (1974). Geology of Sinai Peninsula from ERTs-1 Satellite images Remote Sensing Research project,
Academy of Scientific Research and technology, Cairo, Egypt.

FAO (2006). Guidelines for Soil Profile Description. FAO ISRI, publication, Rome, Italy.

Geological Survey and Mineral Projects Authority, (1994): Map Scal $1: 500.000$ Geol. Surv., Egypt.

Hammad, F. A. (1980). "Geomorphlogical and hydrogeological aspects of Sinai Peninsula, A.R.E. Annals of Geological Survey of Egypt vol. $x$.

Said, R. (1990). The Geology of Egypt. Published for the Egyptian General Petroleum Corporation, Conoco Hurghada Inc. and Repsol Exploracion, S. A. by Balkema, A. A., Rotterdam, Brookfield, the Netherlands.

Soil Survey Staff (2014). Keys to Soil Taxonomy. $12^{\text {th }}$ Edition, United States Department of Agriculture, (USDA), USA.

Sys, C. and W. Verheye (1978). An attempt to the evaluation of physical land characteristics for irrigation according to the FAO framework for land evaluation. Int. Train Course for Post Grad. Soil, Sci. Univ., Ghent, Belgium.

Sys, C., E. van Ranst, J. Debavey and F. Beernaert (1993). Land Evaluation, part III crop Requirements Agricultural Publication No.7 General Administration for Development Cooperation, Gheut, Belgium. 


\section{دراسات جيومورفولوجية وبيدولوجية وتقييم بعض الأراضي في وادي سدر - شبه جزيرة سيناء - مصر}

محمود سليمان محمد، إبراهيم عبد المنعم حجاب، سلوي سعيد السيد

معهد بحوث الأراضي والمياه والبيئة - مركز البحوث الزراعية - الجيزة - مصر

الملخص العربي

وادي سدر أحد أوسع وأهم الأودية الواقعة في جنوب غرب شبه جزيرة سيناء بسبب مصادره الأرضية والمائية الواعدة،

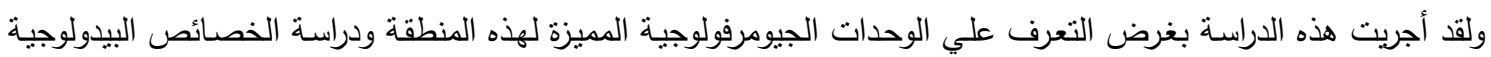
وتقييم الأراضي الممثلة لأهم هذه الوحدات.

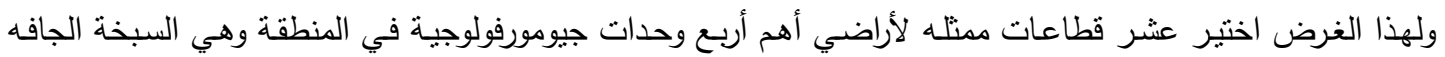

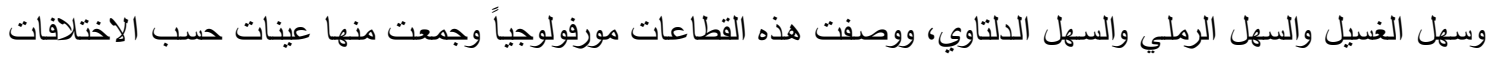

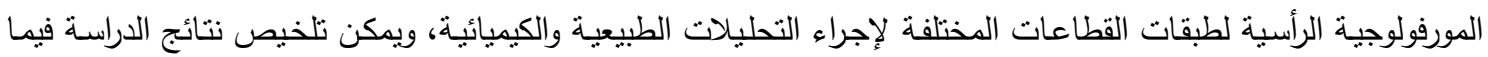
قسمت أراضي مناطق الدراسـة طبقاً لنظام التقسيم الأمريكي الحديث (2014) ، وتتشبر النتائج إلى أن الأراضي تحت

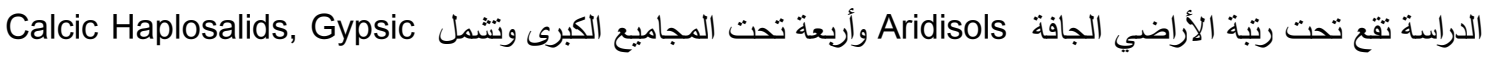
Haplosalids, Sodic Haplocalcids, Typic Haplocalcids عائلات).

أوضحت نتائج تقييم ملائمة هذه الأراضي للاستغلال الزراعي الي أن بعضها ينتمي الي رتبة الأراضي هامشية الصلاحية

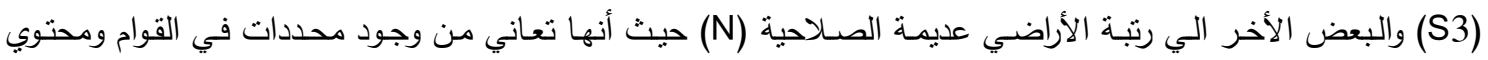

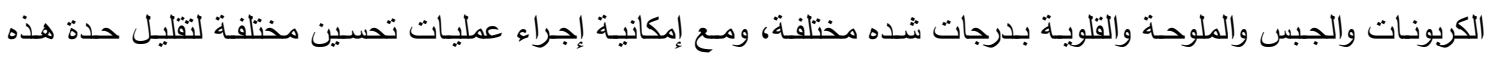
المحددات وإصلاحها وذلك بإضافة المواد العضوية والمحسنات غير العضوية وغسيل الأملاح واستخدام نظم الري الحديثة فإن درجة الملائمة الكامنة لمعظم هذه الأراضي يمكن أن تتحسن الي متوسطة الصلاحية (S2) وهامشية الصلاحية (S3).

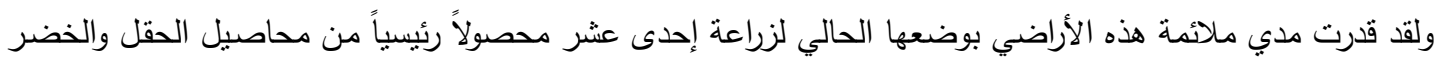

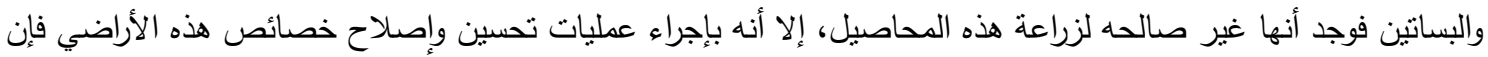
ملاءمنها الكامنة لزراعة المحاصيل يمكن أن تتحسن بدرجه كبيره. 
M.M. Soliman, et al., 